\title{
A Descriptive Study of Organizational Citizenship Behavior in Peruvian Companies
}

\author{
DÍAZ Rosario Almenara1, ALECCHI Beatrice Avolio ${ }^{2}$
}

\begin{abstract}
This research identifies the factors that have an impact on Organizational Citizenship Behavior (OCB) in Peruvian Companies and studies how the employees exhibit or adopt an OCB in the different stages of the business life cycle; identify the context in which the employees adopt an OCB; identify the most relevant forms of OCB for organizational effectiveness; and recognize the main obstacles that hinder the achievement of an OCB. This study uses the qualitative paradigm and the case study method. The purpose of the study is descriptive; it is based on seven propositions related to two phases of the business life cycle: the growth stage and the mature stage. Seven companies that correspond to six different economic sectors have been studied.

According to the study results, the factors and dimensions that have impact on OCB in Peruvian companies are different to the ones used in United States, other western countries, and China, due to the economic phase and to social and cultural aspects in Peru and in the organizations. Other conclusion of the study is that there is not a unique typology of Peruvian companies. Although the research established the company profiles considering the stage of the business life cycle in order to identify comparisons and some patterns of OCB, it has been observed that the proper characterization of each company and other factors or difficulties also have an impact on OCB. The study proposes a model of the factors that determine OCB: the stage of the business life cycle and the level of exhibition of the seven dimensions of OCB, the characteristics of the company, and the factors that contribute and difficulties that hinder the achievement of an OCB. This research will analyze the factors that impact the OCB, which will influence the improvement of organizational efficacy.
\end{abstract}

Keywords: Organizational Citizenship Behavior

JEL: D23

UDK: 005.73:334.7(85)

005.96:005.336.1

COBISS.SR-ID 253488908

\section{Introduction}

Prestigious international organizations, such as the World Economic Forum, the Institute for Management Development, and the World Bank, have measured the level of competitiveness of the economies. In particular, the Global Competitiveness Index published by the World Economic Forum (2011) indicates that the 12 pillars of economic competitiveness are associated not only to the basic requirements, but also to factors that increase innovation, sophistication and efficiency. The factors that increase the labor market efficiency are:

${ }^{1}$ CENTRUM Católica Graduate Business School, rosario.almenara@pucp.edu.pe

${ }^{2}$ CENTRUM Católica Graduate Business School, bavolio@pucp.pe 
flexibility in the labor policies and practices, the efficient use of talent, and, particularly, the cooperation between the worker-employer relationship and the Organizational Citizenship Behavior (OCB) because these relationships can influence the organizational effectiveness, it can enhance the coworker and managerial productivity, the organization's ability to attract and retain the best people, the stability of organizational performance, and the organization's ability to adapt to environmental changes, among others (Podsakoff, MacKenzie, 1997; Organ, Podsakoff, MacKenzie, 2006). In this sense, it is important to understand the factors that determine the level of cooperation within the companies, and to identify and assess the factors that impact the OCB.

The purpose of this research is to study, from a qualitative approach, the OCB in Peruvian companies in order to: (a) identify how the employees exhibit or adopt an OCB in the different stages of the business life cycle; (b) identify the context in which the employees adopt an OCB (for the sake of the individual, group, organization or society); (c) identify the most relevant forms of OCB for organizational effectiveness; and (d) recognize the main obstacles that hinder the achievement of an OCB. A conceptual model of the factors that determine and influence the OCB is also proposed.

The empirical research on OCB is based on studies conducted in developed western countries and in China. The concept of OCB is relatively new in Latin America; therefore, the social and cultural contexts may have impact on the OCB (Farh, Earley, Lin, 1997; Farh, Zhong, Organ, 2004). It is important to add empirical evidence of OCB in different contexts.

This study expands the knowledge of OCB in a social and cultural context different than the existing literature, and uses the case of companies in Peru. Peru, according to the Global Competitiveness Index developed by the World Economic Forum (2011), is ranked $67^{\text {th }}$ out of 142 countries. In regard to the cooperation in employer-employee relations, Peru has a score of 4.6 ( 1 is generally considered to be confrontational and 7 is generally cooperative). The level of cooperation increases the competitiveness and the OCB is part of these employer-employee relations.

\section{Background}

The OCB is the set of behaviors that contribute to the organizational effectiveness and it is one of the precedents of the organizational performance. According to Barker (2006), it is important to assess and have a realistic view of the organizational processes, the nature and meaning of citizenship within organizations, because it is "an attempt to understand the interactions experienced among humans within the workplace structure" (p. 126). Therefore, the OCB is defined as "an individual behavior that is discretionary, not directly or explicitly recognized by the formal reward system which, in the aggregate, promotes the effective functioning of the organization" (Organ et al., 2006, p. 8). The first component is discretionary, which means that the behavior is a personal choice; it is not required in the job description.

The second component is not directly or explicitly recognized by the organizational reward system, i.e. it is not contractually guaranteed by any formal policy and procedure. The third component promotes the efficient and effective operation of the organization.

Prior research on OCB is manly focused on the following aspects: (a) The underlying concepts of the OCB construct, (b) the dimensions of OCB, (c) the background of OCB, (d) the determinants of OCB in the organizations, and (e) the impact of OCB on organizational performance.

Robbins and Judge (2009) studied the behavior of individuals, groups and organizations in order to improve their efficiency. The authors analyzed several factors, such as productivity, absenteeism, rotation and OCB. They defined the latter as a discretionary behavior that promotes the effective functioning in organizations and it is not part of the formal requirements of the job. Several authors studied the variables that impact the organizational behavior and the underlying OCB construct, such as interpersonal cooperation, coordination among the players, 
reputation, trust, and team work. Interpersonal cooperation is a key component for the success of the organization.

Griesinger (1990) noted that the economic role of cooperation is an "interpersonal resource that promises a clear economic advantage for many organizations and significant betterment for most participants" (p. 497). In addition, in regard to the coordination among agents, Crowston (1997) emphasized that the "design of a process depends on the coordination mechanisms chosen to manage dependencies among tasks and resources involved in the process." (p. 157).

The reputation and trust among people, employers, employees, peers and partners are also relevant in organizations. In addition, Sobel (1985), Jones and George (1998), Shmatikov and Talcott (2005), Bottom, Holloway, Miller, Mislin, and Whitford (2006), and Tucker (2008) described the situation in which the person is not sure how to trust the people with whom he/she interacts, conditional and unconditional confidence, the role of agents in the trust relationship, and trust based on the reputation. The characteristics and contextual variables that have an impact on team work have been studied by Dailey (1978), Campion, Papper, and Medsker (1996), Hollenbeck, DeRue, and Guzzo (2004), Mathieu, Maynard, Taylor, Gilson, and Ruddy (2007).

Several researchers have identified the dimensions of OCB (Podsakoff, MacKenzie, Moorman, \& Fetter, 1990; Williams \& Anderson, 1991; Podsakoff \& MacKenzie, 1994; Van Dyne, Graham, \& Dienesch, 1994; Moorman \& Blakely, 1995; Farh et al., 1997; Van Dyne \& LePine, 1998; Podsakoff, MacKenzie, Paine, \& Bachrach (2000); LePine, Erez, \& Johnson, 2002; Farh et al., 2004; and Organ et al., 2006). Podsakoff et al., (2000) pointed out that there is a lack of consensus on the dimensionality of OCB and they organized it in seven dimensions: (a) Helping behavior: when employees voluntarily help others and prevent the occurrence of work-related problems; (b) Sportsmanship: when employees, who are "good sportsmen", do not complain, maintain a positive attitude and are not offended when others reject their suggestions; (c) Organizational loyalty: when employees promote the organization to outsiders, protecting it against external threats and remaining committed to it even under adverse conditions; (d) Organizational compliance: when employees follow the organizational rules and procedures, even when nobody is watching or supervising them; (e) Individual initiative, when the employees carry out higher level tasks than the expected, they improve their tasks showing extra effort, voluntarily engage in additional responsibilities and encourage others to do so; (f) Civic virtue: when the employees are committed to the organization as a whole, to the policies, to monitoring the threats and opportunities, and to do what's best for the organization even at a personal cost; and (g) Self-development: when the employees are voluntarily committed to improve their knowledge, skills and abilities, and to increase the level of contribution to the organization.

Jahangir, Akbar, and Haq (2004) studied the background of OCB, i.e. the factors that promote or hinder the employee's performance in an organization, which will help "to enrich the understanding of how various work conditions affect an employee's willingness to engage in OCB" (p. 82) so that managers can encourage the OCB among the employees in order to achieve the best performance. The variables identified by Jahangir et al., (2004) that may affect the employees' willingness to engage in OCB were: job satisfaction, organizational commitment, leaders' behavior, fairness perception, individual disposition, motivational theories, and the employee's age (p. 81). The authors also emphasized that if managers know the background of the antecedents of OCB, they will be able to promote it among their employees and monitor those behaviors that go beyond the job description and that contribute to the organizational effectiveness.

Personality, leadership and job satisfaction were the studied factors that determined the OCB in the organizations. Organ et al., (2006) mentioned that the theory suggests that personality will predict the OCB better than any other indicator of work performance productivity or technical excellence; however, this prediction is not supported in all research studies. Organ et al., (2006) stated that leaders can influence the employees' motivation and the ability or opportunity to engage in OCB. Podsakoff et al., (1990) found that transformational 
leadership influences the OCB through trust. With regard to job satisfaction, Robbins and Judge (2009) found that when the employees perceive that organizational processes are fair, their confidence is boosted and this generates a greater willingness to voluntarily engage in behaviors that go beyond the formal requirements. Organ et al., (2006) studied the level of commitment of an employee with OCB either for the sake of the employee, for the good of others, or for the good of the organization.

In regard to the impact that OCB has on organizational performance, Podsakoff and MacKenzie (1997) identified the following elements: “(a) enhancing coworker and managerial productivity, (b) freeing up resources so they can be used for more productive purposes, (c) reducing the need to devote scarce resources to purely maintenance functions, (d) helping to coordinate the activities both within and across work groups, (e) strengthening the organization's ability to attract and retain the best employees, (f) increasing the stability of the organization's performance, and (g) enabling the organization to more effectively adapt to environmental changes."

\section{Propositions}

The stage of the business life cycle is crucial in order to study the factors that have an impact on OCB in Peruvian companies. The case study has relied on the theoretical propositions related to the stage of the business life cycle, as a way to guide the case study analysis, help to focus attention on certain data, and define alternative explanations. Two types of companies have been selected in this research: Peruvian companies in a growth stage and Peruvian companies in a mature stage. As Schein (2004) highlighted, the organizational culture and leadership will depend on the organizational stage of the company. In a young company in the growth stage, the culture embedded by the founder who acts as a leader is very important; while in a mature company the culture and leadership are more embedded in the organization.

Leaders embed the beliefs, values, and assumptions through mechanisms that vary among the companies in the way they: (a) pay attention, measure and control; (b) react to critical incidents and crisis; (c) allocate resources; (d) role modeling, teaching, and coaching; (e) allocate rewards and status; and (f) recruit, select, promote, and excommunicate. In young organizations, "design and structure, systems and procedures, rites and rituals, architecture, stories, and formal statements of philosophy, creeds, and charters, are cultural reinforcers, not cultural creators" (Schein, 2004, p. 262). Smith and Gannon (1987) studied the different stages of organizational growth and development, and assessed the organizational structure, reward system, communication process, planning process, formalization and adherence level, judgment level and method of decision making, top level management, organizational growth rate, and organizational age and size, for the entrepreneurial stage, high-growth stage, and maturity stage.

Young companies are in a growth stage and mature companies are in a mature stage.

The seven dimensions of OCB-helping behavior, sportsmanship, organizational loyalty, organizational compliance, individual initiative, civic virtue, and self-development have been evaluated in the two types of companies, identifying how employees behave in companies in a growth stage and in companies in a mature stage.

In the case of helping behavior i.e. when employees voluntarily help others and prevent the occurrence of work-related problems employees in Peruvian companies in the growth stage will tend to help their coworkers more as a result of its early stage of growth and the necessities of this stage. In these companies there is more collectivism, diffuse roles, and individuals have less unilateral actions. According to Quinn and Cameron (1983) who presented a four-stage model, in the second stage of the organizational life cycle the collectivity stage human relation models are important and are related to informal communication and structure, a sense of family and cooperativeness, commitment and personalized leadership.

Proposition 1a: Employees at Peruvian companies in the growth stage will likely exhibit helping behavior more than the employees at Peruvian companies in mature stage. 
Lester and Parnell (2008) highlighted the third Success (Maturity) stage where formalization and bureaucracy are the norm. There is a formal organization structure, job descriptions, procedures, and reporting relationships, and the top management focuses on planning and strategy, leaving daily operations to middle managers. Employees in companies in the mature stage will tend to show sportsmanship behavior when employees who are "good sportsmen", do not complain, maintain a positive attitude, and are not offended when others do not follow their suggestions. Employees at companies in the growth stage will tend to have less sportsmanship, because they are strongly pressured for doing their job and no committee or groups are responsible for important decisions.

Proposition 1b: Employees at Peruvian companies in the growth stage will likely exhibit sportsmanship behavior less than employees at Peruvian companies in the mature stage.

In the case of organizational loyalty i.e. when employees promote the organization to outsiders, protecting against external threats, and remain committed to the organization even under adverse conditions employees at companies in the growth stage will be less likely to have this OCB dimension. Since these companies are in their early stage, they have closed systems, are secretive and are not open to newcomers and outsiders. As Gray and Ariss (1985) pointed out, in the early stage there is a symbolic management policy due to the centralization of power and few connections to external agents, in contrast to the maturity phase, where there are institutionalization power and ideology policies because of the second generation of leadership, i.e. the company is bigger, is managed bureaucratically, and hierarchy and specialization are used to efficiently accomplishing the goals.

Proposition 1c: Employees at Peruvian companies in the growth stage will less likely perform organizational loyalty in comparison with the employees at Peruvian companies in the mature stage.

The organizational compliance which refers to the employee's acceptance and adherence to the rules, regulations, and procedures, even when no one is supervising is more likely to occur at Peruvian companies in the growth stage. Usually, in these companies there is no flexibility and the founder/leader are the one that embedded the culture. Harris and Raviv (2002) emphasized that young firms have a centralized flat structure when the CEO is highly involved in coordination activities.

Proposition 1d: Employees at Peruvian companies in the growth stage will likely demonstrate organizational compliance more than the employees at Peruvian companies in the mature stage.

According to Quinn and Cameron (1983), in the third organizational life cycle (the formalization stage) effectiveness is defined on two models, internal process and rational goals models, which means goal setting and attainment, productivity, information management, communication, and control. In the case of an individual initiative, i.e. when employees engage in task-related behaviors at a level that goes beyond the minimally required, improving one's task, showing extra effort, volunteering on extra responsibilities, and encouraging others to do it. In contrast, employees at companies in the mature stage are more likely to engage in this behavior. These employees are more result oriented and comfortable in unfamiliar situation; each day is a new challenge for them. Employees at companies in the growth stage are less likely to have this behavior.

Proposition 1e: Employees at Peruvian companies in the growth stage will likely engage in individual initiative less than the employees at Peruvian companies in the mature stage.

In the case of civic virtue i.e. when the employee is committed to the organization as a whole, to its governance, to its threats and opportunities, and to look out for the best interest of the organization even at a personal cost the employees at companies in the growth stage are less likely to engage in this behavior. In these companies, the decisions made by the founder/leader change and are usually not predictable. Gupta and Chin (1994) stated that the concern on organizational effectiveness is important in the late growth and maturity stages.

Proposition 1f: Employees at Peruvian companies in the growth stage are likely to exhibit civic virtue less than the employees at Peruvian companies in the mature stage. 
In the case of self-development i.e. when the employees are voluntarily committed to improve their knowledge, skills, and abilities and increase their contribution level in the organization employees at companies in the growth phase are more likely to engage in this behavior. Usually, employees at companies in the early stage of development need to improve their capabilities. It is important to mention that Gupta and Chin (1994), in a three-stage model emphasized that individual effectiveness is important in the early stages. In addition, Randolph and Posner (1982) developed a four-stage model to state that in the second phase (growth phase) the efforts are directed to rationalization, institutionalization, and improving performance.

Proposition 1g: Employees at Peruvian companies in the growth phase are likely to demonstrate self-development more than employees at Peruvian companies in the mature phase.

\section{Method}

The study used a qualitative approach to explore the factors that determine the OCB in the companies and to develop a model that could explain the constructs of OCB in these enterprises. The used qualitative strategy was the case study and the applied technique was the design of multiple case studies embedded by the analysis units evaluated in each case study (Yin, 2003). Multiple sources of evidence (interviews, documentation, files, direct observation, and physical evidence) were also analyzed to interpret each organization considered in the study.

The case studies have been selected based on the 2009 edition of "Peru: The Top 10,000 Companies". From this group, seven companies from different economic sectors were selected.

The "homogeneous sampling of people who are members of a subgroup with distinctive characteristics" (Creswell \& Plano Clark, 2007, p. 112), and "a type of stratified sampling with a specific purpose that illustrates subgroups and facilitates comparisons" (Miles \& Huberman, 1994, p. 28) were used in this study. The aspects considered to select the sample were: (a) large companies which are representative of their economic sector and show a significant growth in recent years; (b) companies concerned in corporate governance; (c) companies that have a significant number of workers; and (d) companies that have implemented human resources management policies and are aware of people management. The informants of the case studies belong to the directive and management level. The number of evaluated case studies has been determined by saturation, which is the decreasing marginal contribution of each additional case (Gummesson, 2000). Logical replication was also used. The research included seven case studies (twenty-four interviews) considering Peruvian companies in the growth and maturity stages (Table 1).

The cases were individually and crosswise analyzed to identify the patterns related to the OCB and the stages of the business life cycle (growth and maturity). The following strategies were used to ensure construct validity: (a) triangulation of the information; (b) a chain of evidence was maintained in the analysis; (c) the researcher's bias was clearly specified; (d) quasi-statistics were carried out to analyze the information related to each particular conclusion (Maxwell, 1996; Creswell, 2003); (e) one pilot case was carried out. To ensure internal validity, the study used the pattern matching strategy; patterns emerging from the comparison of cases provided the bases to establish the conclusions of the research. To ensure reliability, the study used the following strategies: the use of a protocol case, the use of a data base in each case, the of use of an external researcher to verify the contents and logic of the information analysis and to compare the conclusions with the ones the researcher considered as emerging from the information. 
Table 1. Overview of Case Studies Background

\begin{tabular}{|c|c|c|c|c|c|c|c|}
\hline & Case 1 & Case 2 & $\begin{array}{c}\text { Case } \\
3 \\
\end{array}$ & Case 4 & Case 5 & Case 6 & Case 7 \\
\hline $\begin{array}{l}\text { Sector it } \\
\text { belongs } \\
\text { to }\end{array}$ & Mining & Banking & $\begin{array}{c}\text { Banki } \\
\text { ng }\end{array}$ & $\begin{array}{c}\text { Insura } \\
\text { nce }\end{array}$ & Retail & $\begin{array}{c}\text { Equipment } \\
\text { and } \\
\text { Machinery } \\
\text { Trade }\end{array}$ & $\begin{array}{l}\text { Foods and } \\
\text { beverages }\end{array}$ \\
\hline $\begin{array}{l}\text { Type of } \\
\text { Activity }\end{array}$ & $\begin{array}{l}\text { Producti } \\
\text { on of } \\
\text { Goods }\end{array}$ & $\begin{array}{l}\text { Producti } \\
\text { on of } \\
\text { services }\end{array}$ & $\begin{array}{l}\text { Produ } \\
\text { ction } \\
\text { of } \\
\text { Servi } \\
\text { ces } \\
\end{array}$ & $\begin{array}{l}\text { Produc } \\
\text { tion of } \\
\text { Servic } \\
\text { es }\end{array}$ & $\begin{array}{c}\text { Production of } \\
\text { Services }\end{array}$ & $\begin{array}{c}\text { Production of } \\
\text { Services }\end{array}$ & $\begin{array}{l}\text { Production of } \\
\text { Goods }\end{array}$ \\
\hline $\begin{array}{l}\text { Number } \\
\text { of } \\
\text { Informant } \\
\mathrm{s}\end{array}$ & 6 & 4 & 3 & 1 & 4 & 2 & 4 \\
\hline $\begin{array}{l}\text { Years in } \\
\text { Operation }\end{array}$ & $\begin{array}{c}\text { Between } \\
20 \text { and } \\
60\end{array}$ & $\begin{array}{c}\text { More } \\
\text { than } 60\end{array}$ & $\begin{array}{c}\text { Less } \\
\text { than } \\
20 \\
\end{array}$ & $\begin{array}{l}\text { Less } \\
\text { than } \\
20\end{array}$ & Less than 20 & More than 60 & More than 60 \\
\hline $\begin{array}{l}\text { Income } \\
\text { Range } \\
2010 \\
\text { (Million } \\
\text { Soles) }\end{array}$ & $\begin{array}{l}\text { More } \\
\text { than } \\
3,000\end{array}$ & $\begin{array}{l}\text { More } \\
\text { than } \\
3,000\end{array}$ & $\begin{array}{c}\text { Betw } \\
\text { een } \\
1,001 \\
\text { and } \\
2,000\end{array}$ & $\begin{array}{l}\text { Up to } \\
1,000\end{array}$ & $\begin{array}{c}\text { Between } \\
2,001 \text { and } \\
3,000\end{array}$ & $\begin{array}{c}\text { Between } \\
2,001 \text { and } \\
3,000\end{array}$ & $\begin{array}{c}\text { Between } \\
1,001 \text { and } \\
2,000\end{array}$ \\
\hline $\begin{array}{l}\text { Number } \\
\text { of } \\
\text { workers }\end{array}$ & $\begin{array}{c}\text { Between } \\
7,001 \\
\text { and } \\
10,000\end{array}$ & $\begin{array}{c}\text { More } \\
\text { than } \\
10,000\end{array}$ & $\begin{array}{c}\text { Betw } \\
\text { een } \\
4,001 \\
\text { and } \\
7,000\end{array}$ & $\begin{array}{l}\text { Up to } \\
1,000\end{array}$ & $\begin{array}{c}\text { More than } \\
10,000\end{array}$ & $\begin{array}{c}\text { Between } \\
1,001 \text { and } \\
4,000\end{array}$ & $\begin{array}{c}\text { Between } \\
1,001 \text { and } \\
4,000\end{array}$ \\
\hline $\begin{array}{l}\text { Most } \\
\text { representa } \\
\text { tive } \\
\text { category } \\
\end{array}$ & $\begin{array}{l}\text { Manual } \\
\text { workers }\end{array}$ & $\begin{array}{l}\text { Employe } \\
\text { es }\end{array}$ & $\begin{array}{l}\text { Empl } \\
\text { oyees }\end{array}$ & $\begin{array}{c}\text { Emplo } \\
\text { yees }\end{array}$ & $\begin{array}{c}\text { Service } \\
\text { Representativ } \\
\text { es }\end{array}$ & Mechanics & $\begin{array}{l}\text { Manual } \\
\text { workers }\end{array}$ \\
\hline $\begin{array}{l}\text { Gender } \\
\text { with the } \\
\text { highest } \\
\text { participati } \\
\text { on in the } \\
\text { labor } \\
\text { force }\end{array}$ & $\begin{array}{l}\text { Mainly } \\
\text { men }\end{array}$ & $\begin{array}{c}\text { More } \\
\text { women } \\
\text { than men }\end{array}$ & $\begin{array}{c}\text { More } \\
\text { wome } \\
\mathrm{n} \text { than } \\
\text { men }\end{array}$ & $\begin{array}{c}\text { More } \\
\text { woma } \\
\text { n than } \\
\text { men }\end{array}$ & $\begin{array}{l}\text { More men } \\
\text { than women }\end{array}$ & Mainly men & Mainly men \\
\hline
\end{tabular}

\section{Case analysis and results}

\section{$O C B$ in the companies}

The study analyzed how the forms of OCB organized by Podsakoff et al., (2000) helping behavior, sportsmanship, organizational loyalty, organizational compliance, individual initiative, civic virtue and self-development are exhibited or realized in the case studies. For the assessment, the used methodology has made it possible to qualify the presence or absence of the twenty dimensions and to classify the seven forms of OCB as high, medium or low (Table 2).

For the analysis of behavior patterns, the propositions about the seven OCB have been used, in case the company is in a growing stage or in a mature stage.

Based on the informants' testimonies, the study results show that four propositions have been supported, two have been partially supported, and one of them has no impact on the organizational life cycle. These results would reflect that there are certain considerations of the company itself, which have a considerable impact on the exhibition of certain OCB. 
According to the informants' statements, Proposition 1a has been supported. In helping behavior, the spirit of cohesion shown by certain companies has an important influence as a result of the work characteristics or the culture. However, in several case studies, a special mention has been made to the fact that it is not only necessary to promote cooperation, but it is also necessary to train the supervisors to promote cooperation. With regard to the preventive actions taken by the employees, this does not happen in all the cases, since they tend to be more reactive than preventive and, in some cases, these only happen at a corporate level.

In the sportsmanship behavior, two dimensions have been assessed. First, the willingness to do a better job even though there are inconveniences at work. Second, the expression of dissatisfaction due to changes. Based on the informants' statements, Proposition $1 \mathrm{~b}$ is supported. In this aspect, a special emphasis was placed on the importance of communication when changes are made. In some cases, the culture and the characteristics of the company itself make an influence.

In the case of organizational loyalty, according to the business life cycle, Proposition 1c is partially supported as stated by the informants. This is so, because pride towards the company and the employee's commitment, even under adverse conditions, is highly recognized in all the case studies. One factor that has also been mentioned in this behavior is the communication channels and how employees feel they are informed about the important events in the company.

Clarify everything. Look, here we face the world. Not only when there is good news. We have to know the bad news quickly and address them even more quickly. (Case 1 Informant 2 103:103).

In the case of organizational compliance, the focus was on the dimension of rules, standards and procedures compliance even though the employee is not supervised, and the dimension of the good use of the resources. In this behavior, the company culture might have an influence.

According to the informants' statement, Proposition 1d would not apply, since the life cycle has no impact on the measure of this behavior.

According to the informants' statement, Proposition 1e regarding the individual initiative has been supported in the study. It is observed mainly in companies in the mature stage. The aspects to be highlighted in this behavior are the performance of tasks that go beyond the requested duties, the promotion of ideas, opinions and the introduction of improvements among the employees.

We have not done it formally and I believe that is a mistake. I would like to promote that a lot. It is not that I am thinking all day about the employee or the executive, instead the executives shall think about themselves and their development in regard to mine security (Case 1 Informant 5 98:98).

According to the informants' statement, the civic virtue behavior is the least observed in the case studies. This behavior has a smaller presence in companies in a growing stage, which supports the Proposition 1f. From the studied dimensions, the active participation in the governability of the company and the follow-up of threats and opportunities, the level of participation is low or only exhibited by some groups within the company.

Yes, the maximum that can be lowered, especially in the aspects that are part of the vision and mission. During these strategic planning processes, we review the vision and mission every year. This is very interesting, because in this case it is lowered a lot. We give them this and they review it. We don't start from the ground up; we start from what we have nowadays. (Case 7 Informant 1 162:163).

Self-development behavior and its relation with the business life cycle is what Proposition $1 \mathrm{~g}$ refers to and it is not fully supported according to the informants. This result comes from the fact that the employees' desire to improve their knowledge, skills and abilities will be mainly determined by the desire for self-improvement shown by employees in certain companies and because they work in more competitive sectors and not so much because of the life cycle of the company.

The study results of the seven propositions have provided researchers with a vision of organizational processes and of the nature and meaning of citizenship in the organizations. In 
line with Barker (2006), the results show the importance of knowing the managers' scope of the influence and their skill to influence on the desired direction. In addition, the research results would contribute to the conceptualization of the OCB and to build a theory in the future (LePine et al., 2002).

Table 2. Patterns of OCB dimensions

\begin{tabular}{|c|c|c|c|c|c|c|c|c|}
\hline & \multicolumn{4}{|c|}{ Companies in growth stage } & \multicolumn{3}{|c|}{ Companies in maturity stage } \\
\hline & & Case 1 & Case 3 & Case 4 & Case 5 & Case 2 & Case 6 & Case 7 \\
\hline \multirow[t]{5}{*}{$1 \mathbf{a}$} & Helping behavior & High & High & High & High & High & High & Medium \\
\hline & Helping behavior & $(+)$ & $(+)$ & $(+)$ & $(+)$ & $(+/-)$ & $(+)$ & $(+/-)$ \\
\hline & $\begin{array}{l}\text { If Supervisors Promote } \\
\text { Cooperation }\end{array}$ & $(+/-)$ & $(+/-)$ & $(+)$ & $(+)$ & $(+)$ & $(+/-)$ & $(+/-)$ \\
\hline & $\begin{array}{l}\text { Preventive Actions taken } \\
\text { by the Employees }\end{array}$ & $(+/-)$ & $(+/-)$ & $(+/-)$ & $(+/-)$ & $(+)$ & $(+)$ & $(+/-)$ \\
\hline & $\begin{array}{l}\text { Level of Excessive } \\
\text { Cooperation that Affects } \\
\text { Work Performance }\end{array}$ & $(+/-)$ & $(-)$ & $(+)$ & $(-)$ & $(-)$ & $(+/-)$ & $(-)$ \\
\hline \multirow[t]{3}{*}{$1 \mathrm{~b}$} & Sportsmanship & Medium & High & Low & High & High & High & Low \\
\hline & $\begin{array}{l}\text { Willingness to Do Better } \\
\text { even in the Presence of } \\
\text { Problems }\end{array}$ & $(+)$ & $(+)$ & $(-)$ & $(+)$ & $(+)$ & $(+)$ & $(-)$ \\
\hline & $\begin{array}{l}\text { Expression of } \\
\text { dissatisfaction due to } \\
\text { changes }\end{array}$ & $(+)$ & $(-)$ & $(+)$ & $(-)$ & $(+/-)$ & $(-)$ & $(+/-)$ \\
\hline \multirow[t]{5}{*}{$1 \mathrm{c}$} & Organizational loyalty & Medium & High & High & High & High & High & Medium \\
\hline & $\begin{array}{l}\text { Promotion of the } \\
\text { organization to third } \\
\text { parties }\end{array}$ & $(+/-)$ & $(+)$ & $(+)$ & $(+)$ & $(+)$ & $(+)$ & $(+/-)$ \\
\hline & $\begin{array}{l}\text { The employees } \\
\text { communicate important } \\
\text { facts in the organization }\end{array}$ & $(+/-)$ & $(+/-)$ & $(+)$ & $(+)$ & $(+/-)$ & $(+/-)$ & $(+/-)$ \\
\hline & $\begin{array}{l}\text { Willingness of } \\
\text { employees to clarify } \\
\text { misunderstandings }\end{array}$ & $(+/-)$ & $(+)$ & $(+)$ & $(+/-)$ & $(+)$ & $(+/-)$ & $(+/-)$ \\
\hline & $\begin{array}{l}\text { Employee's Commitment } \\
\text { even under adverse } \\
\text { circumstances }\end{array}$ & $(+)$ & $(+)$ & $(+)$ & $(+)$ & $(+/-)$ & $(+)$ & $(+)$ \\
\hline \multirow[t]{3}{*}{$1 \mathrm{~d}$} & $\begin{array}{l}\text { Organizational } \\
\text { compliance }\end{array}$ & Medium & High & High & High & High & High & High \\
\hline & $\begin{array}{l}\text { Compliance with Rules, } \\
\text { Standards and Procedures } \\
\text { even without being } \\
\text { observed }\end{array}$ & $(-)$ & $(+/-)$ & $(+)$ & $(+)$ & $(+)$ & $(+)$ & $(+/-)$ \\
\hline & $\begin{array}{l}\text { Good use of the } \\
\text { organization resources }\end{array}$ & $(+)$ & $(+)$ & $(+)$ & $(+)$ & $(+/-)$ & $(+)$ & $(+)$ \\
\hline \multirow[t]{4}{*}{$1 \mathrm{e}$} & Individual initiative & Low & High & Medium & High & High & High & High \\
\hline & $\begin{array}{l}\text { Performance of tasks that } \\
\text { go beyond the requested } \\
\text { duties }\end{array}$ & $(+/-)$ & $(+)$ & $(+/-)$ & $(+/-)$ & $(+/-)$ & $(+)$ & $(+)$ \\
\hline & $\begin{array}{l}\text { The company promotes } \\
\text { the expression of ideas } \\
\text { and opinions }\end{array}$ & $(-)$ & $(+)$ & $(+)$ & $(+)$ & $(+/-)$ & $(+/-)$ & $(+)$ \\
\hline & $\begin{array}{l}\text { The company encourages } \\
\text { among employees to } \\
\text { introduce improvements } \\
\text { at work }\end{array}$ & $(-)$ & $(+)$ & $(-)$ & $(+/-)$ & $(+)$ & $(+/-)$ & $(+)$ \\
\hline 1f & Civic virtue & Medium & Medium & Low & Low & Medium & High & Medium \\
\hline
\end{tabular}




\begin{tabular}{|c|c|c|c|c|c|c|c|c|}
\hline & \multicolumn{4}{|c|}{ Companies in growth stage } & \multicolumn{3}{|c|}{ Companies in maturity stage } \\
\hline & & Case 1 & Case 3 & Case 4 & Case 5 & Case 2 & Case 6 & Case 7 \\
\hline & $\begin{array}{l}\text { Level of organizational } \\
\text { commitment as a whole }\end{array}$ & (+) & $(+)$ & (+) & (+) & (+) & $(+)$ & $(+)$ \\
\hline & $\begin{array}{l}\text { Employees' willingness } \\
\text { to participate actively in } \\
\text { governance }\end{array}$ & $(+/-)$ & $(+/-)$ & $(-)$ & $(-)$ & $(+/-)$ & $(+/-)$ & $(+/-)$ \\
\hline & $\begin{array}{l}\text { Employees follow up } \\
\text { with the Organizational } \\
\text { opportunities and threats }\end{array}$ & $(+/-)$ & $(+/-)$ & $(+/-)$ & $(-)$ & $(+/-)$ & $(+)$ & $(+)$ \\
\hline & $\begin{array}{l}\text { Employees watch the } \\
\text { company's interest at a } \\
\text { personal cost }\end{array}$ & $(+)$ & $(+)$ & $(+)$ & $(+)$ & $(+/-)$ & $(+)$ & $(+/-)$ \\
\hline $1 \mathrm{~g}$ & Self-development & Medium & High & Medium & Medium & High & Medium & Medium \\
\hline & $\begin{array}{l}\text { Improvement of } \\
\text { Knowledge, Skills and } \\
\text { Abilities by the } \\
\text { Employees }\end{array}$ & $(+/-)$ & $(+)$ & $(+/-)$ & $(+/-)$ & $(+)$ & $(+/-)$ & $(+/-)$ \\
\hline
\end{tabular}

\section{Scope of the OCB}

Organ et al., (2006) studied whether the employee's commitment to an OCB is generated for the sake of the employee (personal gain), for the sake of others (support to the leader and co-workers), or for the sake of the organization (the impact it has on the relevant organizational aspects) and the society in general. Therefore, the study analyzed if the OCB emerge from the employees or not and its scope of action (Table 3). The results show that the prevailing OCB is related to the organization's best interests. This is explained by the employees who feel proud of the company, by their identification with the company, and acknowledge that they're going to grow to the extent that the organization will also grow, as shown in the following cases:

I would say that he wants to feel good and he wants to be in an organization that works well in order to feel good as a person and good in regard to the organization, because he cannot be in an organization that is not good, so to speak. (Case 2 Informant 194:94).

I believe that what they want is to grow and develop along with the organization themselves and as an organization. Exactly. I have seen when the spirit of growth appears. They do not want to stay behind. If the company is growing, there are new opportunities and they want to be prepared to take them, i.e. they grow hand in hand with the company. (Case 5 Informant 4 244:246).

The sake of the group is also important because many employees are identified with the department, group or unit where they work. The sake of the person is ranked third in importance and is determined by the desire for improvement and professional development. Finally, the results show that the sake of the society occurs less frequently and is only relevant for those companies in which the social aspects and the relationship with the environment constitute a crucial part of the corporate policies and strategies.

Table 3. Scope of the employees' OCB

\begin{tabular}{|c|c|c|c|c|}
\hline & $\begin{array}{c}\text { For the person's } \\
\text { sake }\end{array}$ & $\begin{array}{c}\text { For the group's } \\
\text { sake }\end{array}$ & $\begin{array}{l}\text { For the organization's } \\
\text { sake }\end{array}$ & $\begin{array}{c}\text { For the society's } \\
\text { sake }\end{array}$ \\
\hline Case 1 & $\mathrm{x}$ & $\mathrm{x}$ & $\mathrm{x}$ & $\mathrm{x}$ \\
\hline Case 2 & $\mathrm{x}$ & $\mathrm{x}$ & $\mathrm{x}$ & \\
\hline Case 3 & $\mathrm{x}$ & & $\mathrm{x}$ & \\
\hline Case 4 & & $\mathrm{x}$ & $\mathrm{x}$ & \\
\hline Case 5 & $\mathrm{x}$ & $\mathrm{x}$ & $\mathrm{x}$ & $\mathrm{x}$ \\
\hline Case 6 & $\mathrm{x}$ & $\mathrm{x}$ & $\mathrm{x}$ & \\
\hline Case 7 & & $\mathrm{x}$ & $\mathrm{x}$ & $\mathrm{x}$ \\
\hline
\end{tabular}




\section{Forms of OCB and the Impact on Business Management}

The study analyzed which dimensions of OCB were considered to be the most relevant in order to improve the business management and effectiveness. The results show that loyalty and self-development are the behaviors with the greatest impact on organizational management. In four of the seven case studies, loyalty is the most important, while self-development is the most relevant in the other three cases (Table 4), as shown in the following cases:

I believe that self-development and helping behavior are the core subjects. The help, group work and personal growth or self-development make people want to grow, and they use the bank or the organization as a means to accomplish this. (Case 3 Informant 2 122:124)

Table 4. Forms of OCB and the impact on business management

\begin{tabular}{||ll||}
\hline \hline Case 1 & Loyalty is most important. Then optimism, initiative, solidarity, civility and self-development. \\
Case 2 & Self-development and individual initiative. Then compliance, loyalty and helping. \\
Case 3 & Self-development and helping. Also, innovation, sportsmanship and sense of humor. \\
Case 4 & Loyalty and helping. Then sportsmanship, compliance and self-development. \\
Case 5 & Emphasis on self-development. At a lower level, compliance, sportsmanship, helping and team \\
Case 6 & work. At a higher level, self-development, sportsmanship, adaptability to changes. \\
Case 7 & $\begin{array}{l}\text { Organizational loyalty and self-development, the strongest. } \\
\text { Today loyalty, initiative and compliance. What the company wants is for self-development to } \\
\text { be the driver. }\end{array}$ \\
\hline
\end{tabular}

\section{Obstacles for OCB}

The obstacles that may prevent employees from engaging in an OCB are the behaviors that affect efficacy, conflictual situations, constant changes in the company, and a stress level due to changes. Robbins and Judge (2009) mentioned that the deviant behavior in the workplace, the changes and stress may impact the organizational behavior.

According to the informants, the study results show that in three of the seven case studies there are behaviors that affect efficacy, such as the employees' behavior, lack of closeness and communication, union actions, the work environment and the company culture. These factors do no help to achieve an OCB. In the other case studies, the informants mentioned that these behaviors were almost inexistent and were more related to some work-related situations in each specific area that may affect other areas within the organization.

Conflictual situations may also pose obstacles to achieve OCBs. According to the informants, in three case studies there were no conflictual situations. Two case studies had conflictual situations mainly due to union actions or to very different positions among the areas.

In one case study, the informants stated that there were few conflictual situations which might be caused by the lack of communication or by a situation with the supervisor.

With regard to the constant changes in the companies, the informants of five case studies mentioned that changes in the company were a constant feature, and these would continue because the company is growing, it is very dynamic sector, and innovations are constantly introduced into the company. One characteristic of this kind of companies is that they work along with the employees to accept and adapt to each of these changes.

The level of stress is high in six of the seven case studies, according to the informants' statements. Many of these companies are taking action to mitigate the stress with strict work schedule policies, anti-stress programs, coupon books to allow certain schedule flexibility for the collaborator to deal with personal matters, among other activities. Table 5 shows the study results. 
Table 5. Obstacles that hinder the engagement in an OCB

\begin{tabular}{||ccccc||}
\hline \hline & $\begin{array}{c}\text { Behaviors } \\
\text { affecting } \\
\text { efficacy }\end{array}$ & Conflict situations & $\begin{array}{c}\text { Constant changes } \\
\text { in the company }\end{array}$ & $\begin{array}{c}\text { Level of stress } \\
\text { because of } \\
\text { changes }\end{array}$ \\
\hline Case 1 & There is some & There is some & Few changes & A little \\
Case 2 & Minimal & There is none & Constant & High \\
Case 3 & Minimal & There is none & Constant & High \\
Case 4 & There is none & There is none & Few changes & High \\
Case 5 & There is some & Minimal & Constant & High \\
Case 6 & There is none & There is none & Constant & High \\
Case 7 & There is some & There is some & Constant & High \\
\hline
\end{tabular}

\section{Conceptual Framework based on OCB}

The results of the research and the literature review about Organizational Citizenship Behavior (OCB) have allowed proposing a model that includes the factors that determine the OCB (Fig. 1). Three aspects have been taken into account to formulate the model. First, the use of the organizational life cycles a four-stage model to measure the presence or exhibition of the seven OCB dimensions: helping behavior, sportsmanship, organizational loyalty, organizational compliance, individual initiative, civic virtue, and self-development. From the seven propositions studied, four of them were supported, two propositions were partially supported, and one of them has no impact on the organizational life cycle. Second, the characteristics of the companies which includes the leader's influence, the work environment and characteristics of the task the characteristics of the organization, the characteristics of the group work, human resources practices and policies, the use of the talent, and the cooperation relation between the employee and the employer are the variables that influence the OCB and the exhibition of each of the seven dimensions of OCB in the companies. The study results show the importance of these variables in the case studies, regardless of the organizational life cycle. Therefore, it is important to know the level of influence of each characteristic in the OCB. Third, the identification of the factors that contribute to achieve OCBs, which are the following: the level of trust in the company, the level of trust in the boss, the level of satisfaction, and the cultural influence, as well as those that hinder the achievement of OCB, such as behaviors that affect efficacy, conflictual situations, constant changes and stress due to changes. The study shows the factors that contribute to achieve OCBs and the obstacles that prevent companies to achieve OCBs in each study case.

The study of the three aspects has made it possible to identify different patterns of OCB in Peruvian companies, and to assess the tendency to show each of the seven dimensions of OCB, according to the stage of the organizational life cycle. There is not a single typology. The characterizations of each company and the factors or obstacles that hinder the achievement of OCBs in each of them are relevant in the study results. 


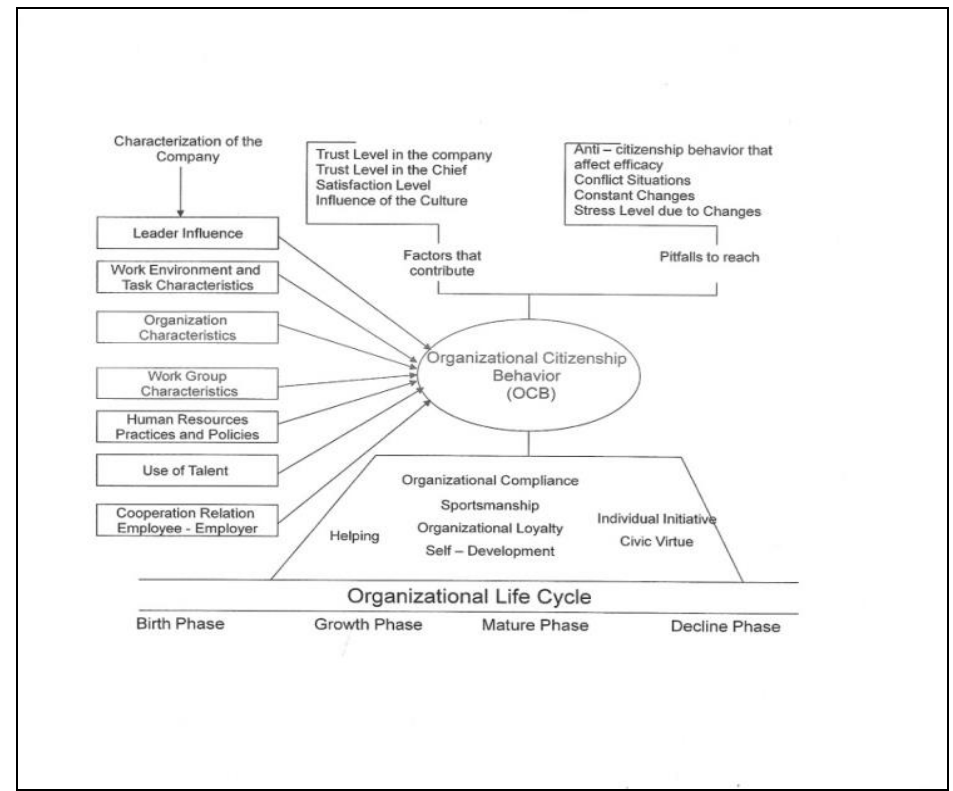

Fig. 1. Model of the factors that determine the Organizational Citizenship Behavior

\section{Discussion}

The study has contributed to the knowledge of OCB as a field of research, for different reasons. First, the qualitative research method has helped to discover the way certain social processes are developed in the organizations, identifying the different patterns of OCB underlying in the companies. Several of the concepts proposed in this study may be used in future research. Second, the use of propositions has guided the case study analysis, identifying companies that are in a growing stage and companies that are in a mature stage. The use of propositions has made it possible to find that, in some cases, the exhibition or the realization of certain OCB to a greater or lesser extent may be determined by the business life cycle, while in other cases, aspects such as the sector, the organizational culture, the demographic characteristics of the employees, and the environment where the operation takes place may have an influence. In addition, certain typologies have been established through the use of propositions. The attention has been focused on specific information and some alternative explanations have been defined. Finally, the research contributed to the proposal of a model to study the different factors to be considered, and established a methodology to assess the degree of the presence or absence of specific dimensions in each one of the seven OCB proposed in the study.

The value of this study is also its contribution to the current literature, with regard to the factors that impact OCB, the context in which the employees adopt an OCB; identify the most relevant forms of OCB for organizational effectiveness; and recognize the main obstacles that hinder the achievement of an OCB.

\section{REFERENCES}

1. Almenara, R. (2012). Un Estudio Descriptivo del Comportamiento de Ciudadanía Organizacional en las Empresas Peruanas (Tesis doctoral). Pontificia Universidad Católica del Perú, Lima, Perú.

2. Barker, R. A. (2006). On Organizational Citizenship. Lanham, MD: University Press of America. 
3. Bottom, W. P., Holloway, J., Miller, G. J., Mislin, A., Whitford, A. (2006). Building a Pathway to Cooperation: Negotiation and Social Exchange between Principal and Agent. Administrative Science Quarterly, 51(1), 29-58.

4. Campion, M. A., Papper, E. M., \& Medsker, G. J. (1996). Relations Between Work Team Characteristics and Effectiveness: A Replication and Extension. Personnel Psychology, 49, 429452.

5. Cavanagh, J. (Ed.). (2009). Peru: The top 10,000 companies. Lima, Peru: Peru Top Publications.

6. Creswell, J. (2003). Research design: Qualitative, quantitative and mixed methods approaches. Thousand Oaks, CA: Sage Publications.

7. Creswell, J. W., Plano Clark, V. L. (2007). Designing and Conducting Mixed Methods Research. Thousand Oaks, CA: Sage Publications.

8. Crowston, K. (1997). A Coordination Theory Approach to Organizational Process Design. Organization Science, 8(2), 157-175.

9. Dailey, R.C. (1978). The Role of Team and Task Characterictics in R\&D Team Collaborative Problem Solving and Productivity. Management Science 24(15), 1579-1588.

10. Farh, J. L., Earley, P. C., Lin, S. C. (1997). Impetus for Action: A Cultural Analysis of Justice and Organizational Citizenship Behavior in Chinese Society. Administrative Science Quarterly, 42(3), 421-444.

11. Farh, J. L., Zhong, C. B., Organ, D. W. (2004). Organizational Citizenship Behavior in the People's Republic of China. Organization Science, 15(2), 241-253.

12. Gray, B., Ariss, S. S. (1985). Politics and Strategic Change across Organizational Life Cycles. The Academy of Management Review, 10(4), 707-723.

13. Griesinger, D. W. (1990). The Human Side of Economic Organization. Academy of Management Review, 15(3), 478-499.

14. Gummesson, E. (2000). Qualitative Methods in Management Research (2 $2^{\text {nd }}$ ed.). Thousand Oaks, CA: Sage Publications.

15. Gupta, Y. P., Chin, D. C. W. (1994). Organizational Life Cycle: A Review and Proposed Directions for Research. The Mid-Atlantic Journal of Business, 30(3), 269-294.

16. Harris, M., Raviv, A. (2002). Organization Design. Management Science, 48(7), 852-865.

17. Hollenbeck, J. R., DeRue, D. S., Guzzo, R. (2004). Bridging the Gap between I/O Research and HR Practice: Improving Team Composition, Team Training, and Team Task Design. Human Resource Management, 43(4), 353-366.

18. Jahangir, N., Akbar, M. M., Haq, M. (2004). Organizational Citizenship Behavior: Its Nature and Antecedents. Brac University Journal, I (2), 75-85.

19. Jones, G. R., George, J. M. (1998). The Experience and Evolution of Trust: Implications for Cooperation and Teamwork. Academy of Management Review, 23(3), 531-546.

20. LePine, J. A., Erez, A., Johnson, D. E. (2002). The Nature and Dimensionality of Organizational Citizenship Behavior: A Critical Review and Meta- Analysis. Journal of Applied Psychology, 87(1), 52-65.

21. Lester, D. L., Parnell, J. A. (2008). Firm size and environmental scanning pursuits across organizational life cycle stages. Journal of Small Business and Enterprise Development, 15(3), 540-554.

22. Mathieu, J. E., Maynard, M. T., Taylor, S. R., Gilson, L. L., Ruddy, T. M. (2007). An examination of the effects of organizational district and team contexts on team processes and performance: a meso- mediational model. Journal of Organizational Behavior, 28, 891-910.

23. Maxwell, J. (1996). Qualitative research design: An integrative approach. Thousand Oaks, CA: Sage Publications.

24. Miles, M. B., Huberman, A. M. (1994). Qualitative Data Analysis: An Expanded Sourcebook. Thousand Oaks, CA: Sage Publications.

25. Moorman, R. H., Blakely, G. L. (1995). Individualism - collectivism as an individual difference predictor of organizational citizenship behavior. Journal of Organizational Behavior, 16(2), 127 142.

26. Organ, D. W., Podsakoff, P. M., MacKenzie, S. B. (2006). Organizational Citizenship Behavior Its Nature, Antecedents, and Consequences. Thousand Oaks, CA: Sage Publications.

27. Podsakoff, P. M., MacKenzie, S. B. (1994). Organizational Citizenship Behaviors and Sales Unit Effectiveness. Journal of Marketing Research, 31(3), 351-363.

28. Podsakoff, P. M., MacKenzie, S. B. (1997). Impact of Organizational Citizenship Behavior on Organizational Performance: A Review and Suggestions for Future Research. Human Performance, 10(2), 133-151. 
29. Podsakoff, P. M., MacKenzie, S. B., Moorman, R. H., Fetter, R. (1990). Transformational Leader Behaviors and Their Effects on Followers' Trust in Leader, Satisafction, and Organizational Citizenship Behaviors. Leadership Quarterly, 1(2), 107-142.

30. Podsakoff, P. M., MacKenzie, S. B., Paine, J. B., Bachrach, D. G. (2000). Organizational Citizenship Behaviors: A Critical Review of the Theoretical and Empirical Literature and Suggestions for Future Research. Journal of Management, 26(3), 513-563.

31. Quinn, R. E., Cameron, K. (1983). Organizational Life Cycles and Shifting Criteria of Effectiveness: Some Preliminary Evidence. Management Science, 29(1), 33-51.

32. Randolph, W. A., Posner, B. Z. (1982). The Effects of an Intergroup Development OD Intervention as Conditioned by the Life Cycle Stage of Organizations: A Laboratory Experiment. Group \& Organization Studies, 7 (3), 335-352.

33. Robbins, S. P., Judge, T. A. (2009). Organizational Behavior. Upper Saddle River, NJ: Pearson Prentice Hall.

34. Schein, E. H. (2004). Organizational Culture and Leadership (3rd ed.). San Francisco: Jossey Bass.

35. Shmatikov, V., Talcott, C. (2005). Reputation - based trust management. Journal of Computer Security, 13, 167-190.

36. Smith, K. G., Gannon, M. J. (1987). Organizational Effectiveness in Entrepreneurial and Professionally Managed Firms. Journal of Small Business Management, 25(3), 14-21.

37. Sobel, J. (1985). A Theory of Credibility. Review of Economic Studies, LII, 557-573.

38. Switzerland: IMD International World Competitiveness Center.

39. Tucker, A. (2008). Trade Associations as Industry Reputation Agents: A Model of Reputational Trust. Business and Politics, 10(1), 1-26.

40. Van Dyne, L., LePine, J. A. (1998). Helping and voice extra - role behaviors: Evidence of construct and predictive validity. Academy of Management Journal, 41(1), 108-119.

41. Van Dyne, L., Graham, J. W., Dienesch, R. M. (1994). Organizational citizenship behavior: Construct redefinition, measurement, and validation. Academy of Management Journal, 37(4), 765-802.

42. Williams, L. J., Anderson, S. E. (1991). Job Satisfaction and Organizational Commitment as Predictors of Organizational Citizenship and in - Role Behaviors. Journal of Management, 17(3), 601-617.

43. World Economic Forum. (2011). In K. Schwab (Ed.), The Global Competitiveness Report 2011 - 2012. Retrieved from http://www3.weforum.org/docs/WEF_GCR_Report_2011-12.pdf

44. Yin, R. K. (2003). Case Study Research Design and Methods (3rd ed.). Thousand Oaks, CA: Sage Publications.

Article history:

- $\quad$ Received 15 June 2017

- $\quad$ Accepted 20 August 2017 